\title{
English Language Teachers' Awareness of English as a Lingua Franca in Multilingual and Multicultural Contexts
}

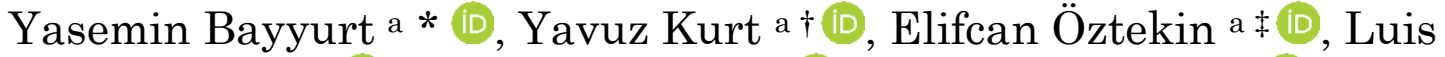 \\ Guerra b§ (D), Lili Cavalheiro ${ }^{c * *}$ (D), Ricardo Pereira ${ }^{d \dagger \dagger}(\mathbb{C}$ \\ a Boğaziçi University, Dept. of Foreign Language Education, Bebek, Istanbul 34342, Turkey \\ ${ }^{b}$ University of Evora, Largo dos Colegiais 2, Évora 7000, Portugal \\ c University of Lisbon, Alameda da Universidade, Lisboa 1600-214, Portugal \\ ${ }^{d}$ Polytechnic of Leiria, Campus 2 - Morro do Lena, Alto do Vieiro, 2411-901 Leiria, Portugal
}

Received 14 June 2018 | Received in revised form 23 May 2019 | Accepted 10 July 2019

\begin{abstract}
APA Citation:
Bayyıurt, Y., Kurt, Y., Öztekin, E., Guerra, L., Cavalheiro, L., \& Pereira, R. (2019). English language teachers' awareness of English as a lingua franca in multilingual and multicultural contexts. Eurasian Journal of Applied Linguistics, 5(2), 185-202. Doi: 10.32601/ejal.599230
\end{abstract}

\begin{abstract} (http://creativecommons.org/licenses/by-nc-nd/4.0/).

\footnotetext{
* Corresponding author. Tel.: +90-212-359-6797

E-mail address: bayyurty@boun.edu.tr

† yavuz.kurt@boun.edu.tr

‡ elifcan.oztekin@boun.edu.tr

$\S$ lspg@uevora.pt

** lilicavalheiro@campus.ul.pt

${ }^{\dagger \dagger} \underline{\text { ricardo.pereira@ipleiria.pt }}$
}

Today English has become the Lingua Franca or common language of many people, regardless of their being native or nonnative speaker of English all over the world. Therefore, it has become necessary to educate pre-/in-service teachers with an awareness towards the significance of the involvement of an "English as a lingua franca" (ELF) perspective in their language teaching practice in multilingual/multicultural contexts. In a rapidly changing world, many English language teachers and teacher trainers are cognizant of the impact of migration in their teaching contexts. However, it is still not very clear to what extent and in what context they are integrating ELF related issues in their language teaching practice. In this study, we make an attempt to unveil in-service teachers' beliefs about ELF in pedagogical practice in three different countries - Poland, Portugal and Turkey. In order to do that we have adopted a questionnaire from an earlier study investigating the involvement of culture in ELT in expanding circle contexts. The findings of the study revealed that although teachers in these contexts are aware of the significance of the inclusion of an ELF-aware perspective in ELT, they are still hesitant about its applicability in their own teaching context. This study has implications for raising English language teachers' awareness in conceptualizing how an ELF-aware pedagogical approach can be implemented in a multilingual/multicultural context.

(C) 2019 EJAL \& the Authors. Published by Eurasian Journal of Applied Linguistics (EJAL). This is an open-access article distributed under the terms and conditions of the Creative Commons Attribution license (CC BY-NC-ND) 
Keywords: English as a lingua franca (ELF); ELF-awareness; in-service teacher education; multilingual/multicultural contexts

\section{Introduction}

\subsection{English as a Lingua Franca in EFL contexts}

Developments in English as a lingua franca (ELF) have often been perceived as an opportunity for thinking about what it means to use, teach and learn an English language that is no more a foreign language to the wide majority of learners around the world (Sifakis, 2014). In this debate, the education of teachers of English as a foreign/second language takes center-stage (Hamid, Zhu \& Baldauf, 2014; Sifakis, 2007, 2009, 2014; Sridhar \& Sridhar, 1986). Teacher training programs can gain from a shift from a traditional EFL/ESL perspective, in which standard varieties of English, most notably British English or General American, are taken as a model, to a more open, inclusive, critical and reflective English language education model with an ELF-aware perspective. In other words, there is an argument for imbuing English language teacher education programs with a reflective awareness of the consequences of the global spread of English for teaching, with the ultimate aim of questioning and even challenging established norms and principles of teaching English to clone native speakers by forcing an idealized native speaker's language use on learners of English. This is the remit of ELF-aware teacher education. This study discusses the implementation of a proposal for educating teachers of English in contexts where English is traditionally a foreign language.

For teacher education programs to succeed, it is important to take into consideration local constraints. Teacher education programs in EFL contexts, like those in China, Italy, Poland, Portugal and Turkey, have had to align teacher training aims and processes with the growing demand for learner competence in English. Each country sets different specifications for qualifying English language teachers. In some countries it is even a must to spend one year abroad in an English-speaking country to become an EFL teacher. For example, in China, there are different institutions specializing in training teachers of English for primary, secondary and tertiary levels. In addition, there are teacher education programs for both pre- and in-service English language teachers, with different requirements. The courses that prepare teachers of English mainly focus on the development of the language skills, and mainly refer to the British and American literature and culture. In China, English has become an obligatory school subject in as recently as 2001, which has brought about an extensive debate on pedagogical models and teacher preparation concerns $(\mathrm{Hu}, 2002 \mathrm{a} ; \mathrm{Hu}$, 2002b). In a similar vein, in Italy, English became a compulsory school subject in primary schools in 2011. The Italian state reviewed its English language teacher education programs to cater for the needs of these new policies. For example, in the Italian context, a new national program known as Tirocinio Formativo Attivo (TFA) was initiated in 2012-2013 aiming to train qualified English language teachers for secondary schools (Pulcini, 2014). The importance of the TFA program is that it was 
the first time that universities were responsible for training teachers of English in the Italian context. Although this program also trains participants in the teaching of English language skills and language testing, trainee teachers can be exposed to information on issues related to the current status of English via examples from World Englishes (WE) and ELF (Lopriore \& Vettorel, 2015; Vettorel, 2015, 2016; Vettorel \& Lopriore, 2013). In Turkey, pre-service teacher education is obligatory to be qualified as an English language teacher. Hence, candidates follow courses for four years in these programs to become teachers. In Portugal to become a qualified ELT teacher, it is necessary to complete either a two-year MA program for teaching an upper-basic and secondary education (years 7-12) or a one-and-a-half-year MA program for teaching English at a primary level (years 3 and 4).

The connection between ELF-awareness and English language teaching has been recently well documented by various researchers in EFL contexts (Bayyurt \& Sifakis, 2015a, 2015b, 2017; Biricik-Deniz, Özkan \& Bayyurt, 2016; Guerra \& Cavalheiro, 2018; Kemaloğlu-Er \& Bayyurt, 2018; Kordia, 2018).

In what follows, we aim at establishing a link between ELF-awareness and its relevance to EFL contexts (Bayyurt \& Sifakis, 2017). Then, we will briefly offer a description of the Turkish, Portuguese and Polish EFL teacher education contexts and constraints arising therein. In this paper, we are adopting a realistic perspective of ELF-awareness and its relevance for the present teacher education programs in these countries. Hence, we will be focusing on the lack of teachers' familiarity with concepts of ELF and its connection with ELT. We will present the results of an ELF-awareness survey conducted in Poland, Portugal and Turkey.

\subsection{Defining ELF}

In its simplest terms, a "lingua franca" is a common language of people whose first languages are different. However, when it comes to English as a lingua franca, it becomes a complex phenomenon with so many non-native speakers of English with diverse linguistic and cultural backgrounds. While explaining the complexity of the defining ELF, Jenkins (2015, p. 73) lists the frequently used definitions of ELF in a chronological order as follows:

- People from different L1 backgrounds use English as a contact language (Jenkins, 2009)

- Use of English as a lingua franca is not only a preferred medium of communication among people with different L1 backgrounds but also the only choice for those people to communicate (Seidlhofer, 2011)

- Use of English in a lingua franca language scenario (Mortensen, 2013)

In all these definitions, the common point is the fact that English is used among people with different L1s and cultural backgrounds. In this respect, it has important implications for investigating this issue further to reveal the significance of the use of ELF in diverse multilingual and multicultural contexts as the language of decision making, negotiation and problem-solving. Jenkins (2015) indicates that it may be 
difficult to comprehend how people use English as a multi-lingua franca as they constantly perform the act of languaging (García, 2007, 2009; Jørgensen, 2008) to achieve their communicative goals. In multilingual contexts individuals may perform poly-languaging - i.e. '... the way in which speakers use features associated with different "languages" - even when they know very little of these "languages" (Jørgensen, Karrebæk, Madsen \& Møller, 2011, p. 22) and/or translanguaging - i.e. “... the act performed by bilinguals of accessing different linguistic features or various modes of what are described as autonomous languages, in order to maximize communicative potential" (García, 2009, p. 140). In this paper, we adopt this up-todate definition of ELF which conceptualizes the multilingual and multicultural characteristics of communication in English with people from diverse linguistic and cultural backgrounds.

\subsection{ELF-awareness in English language teaching and teacher education}

In order to understand how an ELF-aware approach in ELT influences pre-/inservice English language teacher education programs, we need to visit recent literature on the pedagogy of English as a lingua franca. As Bayyurt and Sifakis (2017) rightly put it, the recognition of the functions of English as a global lingua franca positions researchers to address the common beliefs and assumptions about teaching English as far as language teaching methodologies, teacher education, materials design are concerned. Until half a decade ago, leading ELF researchers have been very careful in coming to terms with drawing conclusions about the connection between ELF and ELT (Sifakis \& Bayyurt, 2015). Although Seidlhofer (2004) and Jenkins (2007) made some suggestions about the integration of an ELF perspective in the English language classrooms, they were more careful not to draw easy conclusions about the topic. For example, Jenkins (2012) indicates that it is not the job of researchers to tell teachers what they should do in their English language teaching contexts, however, “... it is for ELT practitioners to decide whether/to what extent ELF is relevant to their learners in their context" (Jenkins, 2012, p. 492). Hence, it is English language teachers who should decide what is relevant for their context as far as ELF research is concerned and implement it in their English language classrooms. In other words, what English language teachers learn in their programs influences their future profession and their ideas about the English language. For example, in Turkey, during the first two years of their studies, preservice teachers take three courses on English literature (two courses on British literature and one course on American literature). When these teachers start their final year of studies, they already think that English belongs to the British or Americans (Biricik-Deniz, 2017; Kemaloğlu-Er, 2017). In the view of this, future English language teachers should be trained with an understanding of what language/language variation means, what types of processes are involved in successful communication, what kind of relationship exists between language and identity, and they should question the suitability of one size fits all approaches in the 
teaching of languages used as a lingua franca like English (Biricik-Deniz et al., 2016; Seidlhofer, 2004).

Bearing this in mind, in this section, we will summarize the approaches of some authors to ELF-awareness and ELT.

Dewey (2012) is one of the first scholars who puts forth the idea of implementing a post normative approach to English language teacher education programs. He states that teachers and teacher educators should question, understand, approve of and, as a result, integrate an ELF-aware approach into their practice through reflecting on their already existing practice and the status of English as a lingua franca all over the world. The aim of Dewey's (2012) proposal for adopting a post-normative approach in ELT is to empower English language teachers, teacher trainers and prospective teachers to be critical of the already existing ELT materials and to produce contextually appropriate materials that are far from normativity. In a similar vein, Blair (2015) notes the need for a new model of ELF-aware teacher education taking a "post-native, multilingual model" of English language user as its basis. He also focuses on raising English language teachers' awareness towards real life professional problems as far as their teaching practices are concerned. Blair (2015) also suggests that an ELF perspective should be incorporated into teacher education programs to raise teachers' awareness towards the sociocultural and sociolinguistic realities of ELF by giving significance to language use as well as usage (Widdowson, 1978). While doing that, Blair (2015) and later on Bayyurt and Sifakis (2015a, 2015b) emphasize how "critical reflection" on ELF- related theory and literature are vital in developing an understanding of ELF and its connection with ELT. In sum, the teaching context is an important element in determining to what extent and how an ELF-aware approach can be adopted in the education programs in those settings. According to Dewey (2012), in order to increase the impact of ELF in ELT, teachers' awareness and understanding of the ELF construct should be further explored and implemented in teacher education programs. In this vein, Bayyurt and Sifakis (2015a, 2015b) developed an ELF-aware teacher education model and carried out their first study with in-service teachers working in both state and private schools in Turkey and Greece. They observe a shift towards an ELF-aware approach in ELT, a shift in the normative mindsets of teachers. In order to achieve an ELF-aware approach to ELT, Bayyurt and Sifakis's (2015a, 2015b) ELF-aware teacher education should be implemented at three levels:

a) Introducing theoretical aspects of ELF through reflective practice;

b) Preparing ELF-aware activities/lesson plans and implementing these in their classrooms.

c) Critical reflection of ELF-aware practice through the evaluation of their implementation of ELF-aware activities/lesson plans.

In order to achieve progress in changing teachers' mindsets about their already existing ELT practice, we should start from theory and continue with the implementation of teachers' newly developed perspectives into their actual teaching 
practice. In this pedagogical approach, the final step is recording teachers' critical reflections on what happens when teachers implement an ELF-aware approach in their classrooms (see Bayyurt \& Sifakis, 2015a, 2015b, 2017; Sifakis, 2014; Sifakis \& Bayyurt, 2015, 2018) for a detailed description and implementation of the model). In this paper, we will explore the extent to which teachers are aware of ELF and whether they are familiar with the idea of ELF-aware teaching. Sifakis and Bayyurt (2018) indicate that ELF-aware teaching and teacher education

... offer opportunities for learning about ELF and experimenting with one's teaching context that prompts teachers to make sense of the shifting times regarding English and explore new, creative and autonomous ways of integrating ELF in their own context. (p. 464).

Since it is beyond the scope of this paper to discuss the implementation of ELFaware teacher education model, we will focus on raising teachers' awareness towards ELF-related issues in ELT.

\subsection{The aim of the study}

This study investigates to what extent ELT teachers are aware of the concepts of ELF, ELF-awareness, culture and nativeness/non-nativeness in their English language teaching practice from an ELF-awareness perspective. In order to do this, we have adapted a questionnaire from an earlier study (Bayyurt \& Erçetin, 2009). The data was collected in three different contexts in Europe - Poland, Portugal and Turkey.

\section{Method}

\subsection{Research design}

This study has an exploratory design and aims to tap into teachers' ELF awareness from various aspects. We have adapted and administered a questionnaire based on another study (Bayyurt \& Erçetin, 2009). Unlike the previous study that tackled with a wide variety of issues on WE, English as an International Language (EIL), and ELF, the present research focuses only on ELF-awareness in ELT - i.e. a construct which is well documented in recent studies (Bayyurt \& Sifakis, 2015a, 2015b, 2017; Biricik-Deniz et al., 2016; Kaçar \& Bayyurt, 2018; Kemaloğlu-Er \& Bayyurt, 2018; Llurda, Bayyurt \& Sifakis, 2018; Sifakis, 2019; Sifakis \& Bayyurt, 2015, 2018). We believe that teachers need to become more and more aware of the changing paradigms as they are teaching more and more in diverse contexts with multilingual and multicultural students.

\subsection{Participant (subject) characteristics and the setting}

We collected data from English language teachers working in Poland, Portugal and Turkey (Table 1). We adopted a convenience sampling approach in selecting the 
participants of the study. The leaders of the research project from each country sent the questionnaire to all of the teachers in their institutions as well as others (i.e., almost all primary, secondary and tertiary schools in their countries). The aim was to get as many teacher responses as possible. The number of teachers who participated from each of these countries was as follows: 40 teachers from Poland, 39 teachers from Portugal and 77 teachers from Turkey. Since this questionnaire was administered electronically, some teachers from other countries also filled out the questionnaire. In this paper, as there are few people from different countries, we only analyze the responses of teachers from Poland, Portugal and Turkey. The total number of the teachers who were included in this study was 159 (118 females and 41 males). Their ages changed between 25 and 60 . The teachers' years of teaching experience showed variation from 5 years to 20 years (Table 1 ).

Table 1: Demographic information about the participants

\begin{tabular}{|c|c|c|c|}
\hline & & Number (total 159) & Percent \% \\
\hline \multirow{2}{*}{ Gender } & Female & 118 & 74.2 \\
\hline & Male & 41 & 25.8 \\
\hline \multirow{6}{*}{ Age } & $<25$ & 35 & 22.0 \\
\hline & $>60$ & 8 & 5.0 \\
\hline & $25-29$ & 18 & 11.3 \\
\hline & $30-39$ & 41 & 25.8 \\
\hline & $40-49$ & 37 & 23.3 \\
\hline & $50-59$ & 20 & 12.6 \\
\hline \multirow{6}{*}{ Nationality } & British & 1 & .6 \\
\hline & Irish & 1 & .6 \\
\hline & Polish & 40 & 25.2 \\
\hline & Portuguese & 39 & 24.5 \\
\hline & Turkish & 77 & 48.4 \\
\hline & US & 1 & .6 \\
\hline \multirow{5}{*}{ Country of employment } & Poland & 39 & 24.5 \\
\hline & Portugal & 43 & 27.0 \\
\hline & Saudi Arabia & 1 & .6 \\
\hline & TRNC & 1 & .6 \\
\hline & Turkey & 75 & 47.2 \\
\hline \multirow{5}{*}{ Years of teaching } & $<5$ & 46 & 28.9 \\
\hline & $>20$ & 47 & 29.6 \\
\hline & $11-15$ & 32 & 20.1 \\
\hline & $16-20$ & 19 & 11.9 \\
\hline & $5-10$ & 15 & 9.4 \\
\hline
\end{tabular}

\subsection{ELF-Awareness questionnaire}

The ELF-awareness questionnaire consists of two major parts. In the first part, there is the demographic features section. In the second part, there is an entire 
section on ELF-awareness. In that section, there are statements related to ELFawareness (please see statements below).

a. Cultural awareness in ELT (9 statements)

b. Language awareness in ELT (11 statements)

c. Instructional awareness in ELT (6 statements)

d. Non-native speaker (NNS) \& Native speaker (NS) interactions (9 statements)

e. NNS \& NNS interactions (9 statements)

In the second section of the questionnaire, the questions are designed as 5-point Likert scale questions. The aim of a Likert scale often involves the measurement of the participants' attitudes, opinions, perspectives and similar. In this questionnaire, the participants were expected to express to what extent they agreed or disagreed with a particular question or statement.

\subsection{Data Collection}

The questionnaire was transferred into electronic format by using Google Surveys (as a tool for transferring the document), and was administered electronically as an open link. Teachers from Portugal, Poland and Turkey were invited via social media (Facebook, WhatsApp, etc.) to participate in the project. The consent of the participants was obtained before administering the questionnaire. The questionnaire was administered between 1 January and 1 March 2018.

\subsection{Data Analysis}

The data were coded on SPSS for statistical analyses. Responses to questionnaire items were coded on ordinal scale (higher numbers associated with agreement and lower number values implicated disagreement with the statement) and reverse coding was implemented for items that included negative statements in order to keep items consistent with the rest of the items pertaining to the topics raised in the questionnaire. Teacher responses to each statement on the questionnaire were examined in percentages to examine general tendencies among the participants. A principal component factor analysis was conducted on the teacher responses in order to establish the validity of the items assessing the constructs related to ELFawareness in the questionnaire. The results of the factor analysis are provided in detail in the following section.

\section{Results}

Teacher responses to items created to measure ELF-awareness are first analyzed to reveal how the items are related to each other under potential sub-constructs of ELF-awareness. Then, the descriptive findings are reported. 


\subsection{Principal Component Analysis}

An exploratory principal component analysis (Jolliffe, 2002) was conducted in order to examine first the distribution of the items on the questionnaire based on factor loadings. In the initial analysis, factors were extracted based on Kaiser's criterion (eigenvalues $>1$ ). This step yielded an eight-factor model; however, when the factor loadings were considered, some factors loaded with only one item and crossloadings were also observed among certain items. When the scree plot, which portrayed the distinctiveness of the derived factors visually based on the variance explained by each factor was examined for this step, a three-factor model appeared to be a more efficient option for the items. Therefore, in order to obtain a more effective model consisting of more comprehensive factors covering more relevant items, a fixed factor extraction method with three factors was implemented, based upon the theoretical division proposed by Sifakis (2019). A varimax rotation, which simplifies the model through changing the vectors of the factors was applied for a more parsimonious model. When the factor loadings of the items were examined, five items had factor loading scores below .40 for any of the three factors, which implied that these items did not reliably correlate with any of the factors derived. Therefore, these items were removed and the analysis was run with the remaining twenty-two items. The rotated factor model revealed that the items were dispersed among three factors, which tapped three possible constructs reflected in the questionnaire: cultural awareness, positioning native varieties and native speakers, and awareness of communication goals. Overall, this three-factor model explained $43.49 \%$ of the total variance (eigenvalues $=4.7,3.1$, and 1.7 respectively, for the three factors; variance $=$ $0.21,0.14$, and 0.7 , respectively for the three factors). The internal consistency of the questionnaire was also examined calculating Cronbach's alpha values. The internal consistency of the overall questionnaire with all items included was $\alpha=.739$. The Cronbach's alpha values were $.419, .851$, and .537 respectively for the three factors.

The first factor was named "cultural awareness" as it emerged as a quite distinct construct raised with six items that loaded with the first factor. The second factor was named "positioning native varieties/speakers" with ten items loaded, while the third factor was named "awareness of communication goals", with six items loaded. The responses from the teachers were examined in the light of this three-factor model derived from the questionnaire regarding the ELF-awareness construct. The following section reports the percentages of the teacher responses under each response option (based on the 5-point Likert scale options) per item categorized under the three factors derived in the principal component factor analysis.

\subsection{Teacher Responses}

With reference to Table 2, teacher responses indicated that there was a clear tendency among teachers to accept the importance of culture in language education. Most of the teachers indicated that language learners needed to be aware of differences and similarities between cultures. In this respect, teachers were aware of 
the fact that they were living and working in diverse linguistic and cultural settings where English traditionally functioned as a foreign language. However, with the increasing number of people immigrating to different countries in and around Europe due to war, better job opportunities, educational purposes, English has become a multi-lingua franca in and around the participant countries in this project. Hence, cultural awareness is an inevitable outcome of this part of the questionnaire.

Table 2. Cultural awareness

\begin{tabular}{|c|c|c|c|c|c|}
\hline \multirow{2}{*}{ Survey items on cultural awareness } & \multicolumn{5}{|c|}{ Teacher responses in percentages } \\
\hline & 1 & 2 & 3 & 4 & 5 \\
\hline $\begin{array}{l}\text { Non-native speakers of English should learn about both the target } \\
\text { language culture and other cultures to communicate successfully in } \\
\text { English. }\end{array}$ & 0 & 2.5 & 10.1 & 49.1 & 38.4 \\
\hline $\begin{array}{l}\text { It is essential to teach the students the similarities and differences } \\
\text { between the native English speaking countries and their own } \\
\text { country. }\end{array}$ & 1.3 & 4.4 & 14.5 & 52.8 & 27 \\
\hline $\begin{array}{l}\text { Students do not need to know about the cultures of native speakers } \\
\text { of English to communicate successfully in English. }\end{array}$ & 39.6 & 37.7 & 8.8 & 10.7 & 3.1 \\
\hline $\begin{array}{l}\text { Students need to know about the similarities and differences } \\
\text { between their own culture and other cultures. }\end{array}$ & 0.6 & 5 & 6.9 & 54.7 & 32.7 \\
\hline
\end{tabular}

Note. $\mathrm{N}=159,1=$ strongly disagree, $2=$ disagree, $3=$ neutral, $4=$ agree, $5=$ strongly agree

Moreover, these teachers also seemed to appreciate the importance of both the cultures of native speakers (agree + strongly agree $=50.2 \%$ ) and the cultures of the non-native English speaking world (agree + strongly agree $=63.5 \%$ ).

Table 3 below shows that the responses of teachers on items regarding native varieties and native speakers of English did not show a clear tendency. Teachers provided rather dispersed responses on the agreeing and disagreeing continuum. They appeared to be either undecided or divided between attaching importance to native like proficiency and accent or not. 
Table 3. Positioning native varieties and native speakers

\begin{tabular}{|c|c|c|c|c|c|}
\hline \multirow{2}{*}{ Survey items on positioning native varieties and native speakers } & \multicolumn{5}{|c|}{ Teacher responses in percentages } \\
\hline & 1 & 2 & 3 & 4 & 5 \\
\hline $\begin{array}{l}\text { It is more important for students to be able to communicate with } \\
\text { native speakers of English than non-native speakers of English. }\end{array}$ & 11.3 & 33.3 & 29.6 & 18.2 & 6.9 \\
\hline $\begin{array}{l}\text { In learning English, the ultimate goal should be reaching native- } \\
\text { like proficiency. }\end{array}$ & 12.6 & 28.9 & 27 & 25.8 & 5 \\
\hline $\begin{array}{l}\text { English has many varieties, but to be practical we should only } \\
\text { teach American or British English. }\end{array}$ & 11.3 & 27 & 27 & 28.9 & 4.4 \\
\hline Students should be able to speak English with a native-like accent. & 11.9 & 35.8 & 24.5 & 23.3 & 3.8 \\
\hline $\begin{array}{l}\text { Materials should include written or spoken texts only produced by } \\
\text { native speakers of English. }\end{array}$ & 13.8 & 34.6 & 16.4 & 21.4 & 13.2 \\
\hline $\begin{array}{l}\text { Native English-speaking teachers (NESTs) should speak English } \\
\text { with a British or American accent. }\end{array}$ & 6.9 & 27.7 & 26.4 & 29.6 & 9.4 \\
\hline NNESTs must have a Standard English accent. & 8.2 & 27.7 & 23.9 & 34 & 5.7 \\
\hline $\begin{array}{l}\text { Non-native English-speaking teachers (NNESTs) should speak } \\
\text { English with a British or American accent. }\end{array}$ & 11.9 & 32.7 & 27.7 & 20.8 & 6.3 \\
\hline NNESTs must have a Standard English accent. & 9.4 & 23.9 & 20.8 & 34.6 & 11.3 \\
\hline $\begin{array}{l}\text { NNESTs must rely on native-speaker models to communicate } \\
\text { successfully in English }\end{array}$ & 8.8 & 20.8 & 23.3 & 36.5 & 10.7 \\
\hline
\end{tabular}

Note. $\mathrm{N}=159,1=$ strongly disagree, $2=$ disagree, $3=$ =neutral, $4=$ agree, $5=$ =strongly agree

Although a higher percentage of teachers indicated opposition to the fact that the teaching materials should feature only native speaker texts (disagree + strongly disagree $=48.4 \%$ ), a considerable number of them supported the idea (agree + strongly agree $=34.6 \%$ ). The high percentage of undecided teachers on this component of the survey (average $=24.7 \%$ ) showed that teachers were not sure how to position native speaker varieties and native speakers in their profession.

The final factor that emerged from the previous analyses had items related to communication goals. As shown in Table 4, responses on this component show that teachers agreed on the importance of intelligibility in international communication (agree + strongly agree $=66.2 \%$ ) and the fact that students needed to communicate with native and non-native speakers of English (agree + strongly agree $=91.8 \%$ ).

Table 4. Awareness of communication goals

\begin{tabular}{|c|c|c|c|c|c|}
\hline \multirow{2}{*}{ Survey items on awareness of communication goals } & \multicolumn{5}{|c|}{ Teacher responses in percentages } \\
\hline & 1 & 2 & 3 & 4 & 5 \\
\hline $\begin{array}{l}\text { Students need to learn English to communicate with native and non- } \\
\text { native speakers of English. }\end{array}$ & 0 & 1.9 & 6.3 & 41.5 & 50.3 \\
\hline $\begin{array}{l}\text { Intelligible accent is essential for successful communication among } \\
\text { native and non-native speakers of English. }\end{array}$ & 3.8 & 9.4 & 20.1 & 45.3 & 20.8 \\
\hline $\begin{array}{l}\text { Accurate grammar is essential for successful communication among } \\
\text { native and non-native speakers of English. }\end{array}$ & 5.7 & 27.7 & 29.6 & 32.1 & 3.8 \\
\hline $\begin{array}{l}\text { Exposing students to non-native varieties of English has an impact } \\
\text { on students' language learning. }\end{array}$ & 1.9 & 10.1 & 26.4 & 48.4 & 12.6 \\
\hline NESTs must have a Standard English accent. & 3.1 & 6.9 & 12.6 & 42.8 & 34.6 \\
\hline NESTs' job is to teach students how to communicate in English. & 1.3 & 3.8 & 10.7 & 47.8 & 36.5 \\
\hline
\end{tabular}

Note. $\mathrm{N}=159,1=$ strongly disagree, $2=$ disagree, $3=$ neutral, 4=agree, $5=$ strongly agree 
Interestingly, these teachers appeared to have quite different views about the role of accuracy for successful communication. The percentage of those who agreed that accuracy was necessary for successful communication (agree + strongly agree $=35.9 \%$ ) and those who disagreed (disagree + strongly disagree $=33.4 \%$ ) are close to each other. Furthermore, a respectable percentage of teachers expressed that they were neutral regarding the role of accuracy. The teachers indicated that they did not see accuracy vital for successful communication since they were in multilingual/multicultural context where the significant thing was the intelligibility of the message (Bayyurt, 2018).

The final part of the survey investigates how teachers rated a number of aspects in native - non-native and non-native - non-native interactions in terms of their importance. The pattern of results presented in Table 5 are quite similar for NS-NNS and NNS-NNS interactions.

Table 5. Teacher ratings on aspects of NS-NNS and NNS-NNS interactions

\begin{tabular}{|c|c|c|c|c|c|c|c|c|c|c|}
\hline \multirow{3}{*}{ Item } & \multicolumn{10}{|c|}{ Teacher responses in percentages } \\
\hline & \multicolumn{2}{|l|}{1} & \multicolumn{2}{|l|}{2} & \multicolumn{2}{|l|}{3} & \multicolumn{2}{|l|}{4} & \multicolumn{2}{|l|}{5} \\
\hline & $\begin{array}{l}\text { NS- } \\
\text { NNS }\end{array}$ & $\begin{array}{l}\text { NNS- } \\
\text { NNS }\end{array}$ & $\begin{array}{l}\text { NS- } \\
\text { NNS }\end{array}$ & $\begin{array}{l}\text { NNS- } \\
\text { NNS }\end{array}$ & $\begin{array}{l}\text { NS- } \\
\text { NNS }\end{array}$ & $\begin{array}{l}\text { NNS- } \\
\text { NNS }\end{array}$ & $\begin{array}{l}\text { NS- } \\
\text { NNS }\end{array}$ & $\begin{array}{l}\text { NNS- } \\
\text { NNS }\end{array}$ & $\begin{array}{l}\text { NS- } \\
\text { NNS }\end{array}$ & $\begin{array}{l}\text { NNS- } \\
\text { NNS }\end{array}$ \\
\hline $\begin{array}{l}\text { Gestures/facial } \\
\text { expressions }\end{array}$ & 1,3 & 1,3 & 2,5 & 1,3 & 13,2 & 1,9 & 34,6 & 12,6 & 48,4 & 42,1 \\
\hline Vocabulary & 0 & 1,3 & 0,6 & 1,3 & 5 & 11,3 & 48,4 & 50,3 & 45,9 & 34,6 \\
\hline Accent & 5.7 & 6.9 & 16.4 & 16.4 & 36.5 & 34.6 & 28.9 & 30.8 & 11.9 & 10.1 \\
\hline $\begin{array}{l}\text { Knowledge of } \\
\text { grammar }\end{array}$ & 2.5 & 4.4 & 12.6 & 15.1 & 31.4 & 30.2 & 37.1 & 34.6 & 16.4 & 14.5 \\
\hline $\begin{array}{l}\text { Establishing one's } \\
\text { own identity }\end{array}$ & 3.8 & 3.1 & 2.5 & 6.3 & 22 & 19.5 & 53.5 & 51.6 & 18.2 & 17.6 \\
\hline $\begin{array}{l}\text { Knowing about the } \\
\text { native-speaker } \\
\text { culture }\end{array}$ & 2.5 & 7.5 & 6.9 & 11.3 & 19.5 & 23.9 & 52.2 & 38.4 & 18.9 & 17.6 \\
\hline $\begin{array}{l}\text { Knowing about the } \\
\text { non-native-speaker } \\
\text { culture }\end{array}$ & 1.9 & 2.5 & 8.8 & 8.8 & 24.5 & 27 & 49.7 & 42.8 & 15.1 & 17.6 \\
\hline $\begin{array}{l}\text { Use of } \\
\text { communication } \\
\text { strategies (e.g. } \\
\text { repetition, } \\
\text { rephrasing, } \\
\text { codeswitching, etc.) }\end{array}$ & 0.6 & 0.6 & 3.8 & 6.3 & 9.4 & 9.4 & 39 & 43.4 & 47.2 & 38.4 \\
\hline $\begin{array}{l}\text { Use of the language } \\
\text { according to native } \\
\text { speaker norms }\end{array}$ & 10.1 & 10.1 & 8.2 & 13.8 & 27 & 28.3 & 40.9 & 34 & 13.8 & 12.6 \\
\hline
\end{tabular}

Note. NS-NNS=Native and non-native interactions, NNS-NNS=Non-native interactions, $1=$ Not important, 2=Slightly important, 3=Moderately important, 4=Important, 5=Very important

In general terms, all aspects included in the questionnaire are mostly rated moderately important, important or very important; however, the importance attached to some aspects was remarkably higher. For example, accent, knowledge of grammar, establishing one's own identity, knowing about the native speaker culture, 
knowing about the non-native speaker culture, and use of the language according to native speaker norms were usually rated as moderately important or important. On the other hand, gestures, vocabulary, and use of communication strategies were rated important or very important. Similar responses for NS-NNS and NNS-NNS interactions indicate that the respondent teachers did not make a distinction between the two kinds of interaction. In sum, although it is not stated or expressed explicitly, the teachers seem to be aware of the changing paradigms and wanted to receive further training in this respect.

\section{Discussion}

In this study, we wanted to see to what extent English language teachers from three different countries were aware of ELF in their English language classrooms. The findings suggest that there is a disconnection between what teachers believe, how they perceive the ELF construct and their teaching practices as revealed in previous studies (Bayyurt \& Sifakis, 2015a, 2015b). In this section, we will discuss these issues in relation to the findings of the current study.

In the first phase of the analysis when we applied the rotated factor model, three factors emerged to bear three possible constructs in the questionnaire: cultural awareness, positioning native varieties and native speakers, and awareness of communication goals. The findings indicated that participant teachers' awareness of the need to communicate in English was not restricted to native speaker communities. They also agreed that intercultural awareness was important for language users. These findings could be interpreted as the changing conceptualizations of English language and pedagogy among language teachers in various contexts. Nevertheless, their tendency to see the native speaker as a yardstick and the importance they attach to linguistic accuracy perhaps show that a traditional EFL perspective is still preferred by English language teachers (Illés \& Csizér, 2015). However, how these tendencies relate to English language teachers' awareness of ELF depend on their local contexts. In different contexts, teachers may have different conceptualizations of $\mathrm{ELF}$, and there can be a number of factors influencing their English language teaching practice, such as, the presence of immigrants in their classrooms, linguistic and cultural differences between the immigrants and locals, attitudes of local students towards immigrants.

Previous studies have documented that although teachers seem to welcome the idea of an ELF approach in their teaching practice, teachers do not know how to implement an ELF-aware approach to their language teaching materials since such materials hardly exist in the field (Bayyurt \& Sifakis, 2015a, 2015b; Kemaloğlu-Er \& Bayyurt, 2018; Sifakis \& Bayyurt, 2018). The results of the current study showed that teachers favor the idea that cultural diversity should be integrated into the English language teaching materials. In other words, they supported the idea that the cultures of both native speakers and nonnative speakers should be part of the English language classrooms (Bayyurt, 2006, 2017). However, a great majority of the teachers 
in this study seem to be indecisive about the role of the inclusion of the non-standard varieties of English in their language teaching practice. In addition, the teachers, who participated in the study, had differing views on the role of grammatical accuracy in successful communication. While some of them agreed to the idea, others were not sure about what the role of grammatical accuracy is in successful communication (Bayyurt \& Sifakis, 2015a, 2015b). Moreover, they did not show a clear tendency towards supporting the idea that nonnative teachers should have a native-like competence-accent or native-like proficiency. Teachers highlighted the idea that intelligibility was more important than having a native-like accent especially in multilingual and multicultural contexts.

Although these results support the findings of earlier studies (Bayyurt, 2017; Bayyurt and Sifakis, 2015a, 2015b; Biricik-Deniz, 2017; Biricik-Deniz et al., 2016; Kemaloğlu-Er, 2017) on pre- and in-service teachers' perceptions of ELF and its involvement in ELT, in this study, the intention of the researchers was not to generalize the results to the whole population of English language teachers in their contexts. Moreover, since this study was designed to develop and validate a tool on ELF awareness of English language teachers in three different contexts, it did not involve the actual classroom practices of teachers or the differences among these countries - i.e. Poland, Portugal and Turkey. Therefore, it does not target teachers' integration of ELF awareness into their teaching in different contexts. This is again an important question to investigate in a future study.

Since this paper only reports the development and validation of the ELF awareness questionnaire, it does not deal with the reasons behind teachers' views through followup interviews. However, previous research has enabled us to gain insights into how teachers understand their role as professionals. For example, Bayyurt and Sifakis's study (2015b) says:

... I have always thought that native speaker teachers are better than nonnative speakers even though I have read some articles related to global English. I have never questioned the issue of who is better? But, now I'm very confident of myself that I teach the English which is useful for my students. I may not teach a perfect English to a Pakistani student because I do not have any idea about his/her cultural norms and life. However, I know my students and their life, their way of learning English, so I'm sure I can teach better than any other native speaker teacher or non-native speaker teacher who is not Turkish... (p. 126)

This quotation indicates that teachers might not be aware of the fact that they belong to a larger group of teachers who come from diverse linguistic and cultural backgrounds and who teach English in a non-English L1 speaking context where English is spoken as a foreign or second language. In addition, teachers should see their assets as non-native English language teachers in teaching English to speakers of other languages, including the ones from their first language (Seidlhofer, 1999). 
The findings of the current study confirm Bayyurt and Sifakis's (2015a, 2015b; 2017) and Sifakis's $(2007,2014,2019)$ theoretical predictions and practical applications on raising teachers' awareness towards issues of ELF-awareness and adoption of an ELF-aware perspective in ELT in a constantly changing multilingual and multicultural world.

\section{Conclusion}

In this study, we aimed at seeing to what extent teachers from three different countries are aware of the involvement of ELF in ELT. Although the findings here indicate that teachers do not ignore the need to interact with non-native speakers of English or the need to gain intercultural competence, their responses on the questionnaire also show that they still particularly value native speaker norms as a reference point. Therefore, the results indicated that these teachers need to be educated to become ELF-aware and understand ways of integrating an ELF-aware perspective into their teaching. For example, using videos and audios including nonnative varieties of English used in international contexts.

Therefore, it is important to conduct further research in these contexts to understand how the teachers in each of these countries conceptualize ELF and ELFawareness in their ELT practice. As Sifakis and Bayyurt (2018) further indicate, after all "Being and ELF-aware teacher means finding ways to empower one's learners as competent non-native users of English, essentially prompting them to become ELFaware users themselves" (p. 464). Once teachers become ELF-aware themselves, they can teach English to learners to become competent and confident ELF-aware users of English. In a changing world where people are in a constant movement - i.e. migration as a result of wars, economic and political reasons - a new perspective of a common language should be well understood and its pedagogies developed. Hence, it is important to raise English language teachers' awareness towards teaching English in multilingual and multicultural classrooms as well as the merits of becoming and ELF-aware teacher to be able to teach effectively in such diverse contexts.

\section{Acknowledgements}

This study is a part of the Erasmus + project entitled ILTERG "International Language Teacher Education Research Group". It is supported by the Turkish National Agency project number 2016-1-TR01-KA203-035295. We would like to thank all of the English language teachers from Poland, Portugal and Turkey who took part in this project.

\section{References}

Bayyurt, Y. (2006). Non-native English language teachers' perspective on culture in English as a Foreign Language classrooms. Teacher Development, 10(2), 233-247. 
Bayyurt, Y. (2017). Non-native English language teachers' perceptions of "culture" in English language classrooms in a post-EFL era. In J. de Dios Martinez Agudo (Ed.), Native and Non-Native Teachers in Second Language Classrooms: Professional Challenges and Teacher Education (pp. 139-159). Berlin: De Gruyter.

Bayyurt, Y. (2018). Issues of intelligibility in world Englishes and EIL contexts. World Englishes, 37(3),407-415.

Bayyurt, Y., \& Erçetin, G. (2009). The role and significance of the concept of "culture" in English language teaching: A pedagogical approach. Unpublished research report, TUBITAK (The Scientific and Technical Research Council of Turkey), Project Number: 104K085, Ankara, Turkey.

Bayyurt, Y., \& Sifakis, N. (2017). Foundations of an EIL-aware teacher education. In A. Matsuda (Ed.), Preparing teachers to teach English as an International Language (pp. 3-18). Bristol: Multilingual Matters.

Bayyurt, Y., \& Sifakis, N. C. (2015a). Developing an ELF-aware pedagogy: Insights from a self-education programme. New frontiers in teaching and learning English, 55-76.

Bayyurt, Y., \& Sifakis, N. C. (2015b). ELF-aware in-service teacher education: A transformative perspective. In H. Bowles, \& A. Cogo (Eds.), International Perspectives on English as a Lingua Franca (pp. 117-135). Basingstoke, UK: Palgrave Macmillan.

Biricik-Deniz, E. (2017). A case study on ELF-aware pre-service language teacher education model: Theory into practice. Unpublished PhD Thesis, Çukurova University, Adana, Turkey.

Biricik-Deniz, E., Özkan, Y., \& Bayyurt, Y. (2016). English as a Lingua Franca: Reflections on ELF-Related Issues by Pre-Service English Language Teachers in Turkey. The Reading Matrix, 16(2), 144-161. http://readingmatrix.com/files/15-7lew266j.pdf

Blair, A. (2015). Evolving a post-native, multilingual model for ELF-aware teacher education. In Y. Bayyurt \& S. Akcan (Eds.) Current perspectives on pedagogy for English as a lingua franca (pp. 89-102). Berlin: De Gruyter Mouton.

Dewey, M. (2012). Towards a post-normative approach: Learning the pedagogy of ELF. Journal of English as a Lingua Franca 1(1), 141-170.

García, O. (2007). Lenguas e identidades en mundos hispanohablantes. Desde una posición plurilingüe y minoritaria. In M. Lacorte (Ed.), Lingüística aplicada del español (pp. 377400). Madrid: Arco.

García, O. 2009. Education, multilingualism and translanguaging in the 21st century. In A. Mohanty, M. Panda, R. Phillipson, \& T. Skutnabb-Kangas (Eds.), Multilingual Education for Social Justice: Globalising the Local (pp. 128-145). New Delhi: Orient Blackswan.

Guerra, L., \& Cavalheiro, L. (2018). When the textbook is not enough: How to shape an ELF classroom? In N.C. Sifakis \& N. Tsantila (Eds.), English as a lingua franca for EFL contexts (pp. 117-131). Bristol: Multilingual Matters.

Hamid, M., Zhu, L., \& Baldauf, R. B. (2014). Norms and varieties of English and TESOL teacher agency. Australian Journal of Teacher Education, 39(10), 77-95. http://dx.doi.org/10.14221/ajte.2014v39n10.6

Hu, G. W. (2002a). Recent important developments in secondary English-language teaching in the People's Republic of China. Language, Culture and Curriculum, 15, 30-49.

$\mathrm{Hu}$, G. W. (2002b). Potential cultural resistance to pedagogical imports: The case of communicative language teaching in China. Language, Culture and Curriculum, 15, 93-105.

Illés, É., \& Csizér, K. (2015). The disposition of Hungarian teachers of English towards the international use of the English language. In D. Holló \& K. Károly (Eds.), Inspirations in 
foreign language teaching: Studies in applied linguistics, language pedagogy and language teaching (pp. 170-183). London, UK: Pearson Education.

Jenkins, J. (2007). English as a lingua franca: Attitude and identity. Oxford: Oxford University Press.

Jenkins, J. (2009). English as a Lingua Franca: Interpretations and attitudes. World Englishes, 28(2), 200-207.

Jenkins, J. (2012). English as a Lingua Franca from the classroom to the classroom. ELT Journal, 66(4), 486-494.

Jenkins, Jennifer (2015) Repositioning English and multilingualism in English as a Lingua Franca. Englishes in Practice, 2 (3), 49-85.

Jolliffe, I.T. (2002) (2nd ed.). Principal component analysis. New York, NY: Springer.

Jørgensen, J. N. (2008). LANGUAGING: Nine years of poly-lingual development of young Turkish-Danish grade school students. Copenhagen: Røde Hane (retrieved from https://andetsprogsforskning.ku.dk/forskning/koebenhavnerstudier_i_tosprogethed_/manus kripter/Bind_K15___J._N._J_rgensen_-_Languaging_-_Vol._1.pdf)

Jørgensen, J. N., Karrebæk, M. S., Madsen, L. M., \& Møller, J. S. (2011). Polylanguaging in superdiversity. Diversities, 13(2), 23-37.

Kaçar, I. G., \& Bayyurt, Y. (2018). ELF-aware pre-service teacher education to promote glocal interactions: A case study in Turkey. In A. F. Selvi \& N. Rudolph (Eds.), Conceptual shifts and contextualized practices in education for glocal interaction - Issues and implications (pp. 77-104). Singapore: Springer.

Kemaloğlu-Er, E. (2017). Integrating ELF-awareness into pre-service teacher education: Insights from theory and practical experience. Unpublished doctoral thesis, Boğaziçi University, Istanbul, Turkey.

Kemaloğlu-Er, E., \& Bayyurt, Y. (2018). ELF-awareness in teaching and teacher education: Explicit and implicit ways of integrating ELF into the English language classroom. In N.C. Sifakis \& N. Tsantila (Eds.), English as a lingua franca for EFL contexts (pp. 159-174). Bristol: Multilingual Matters.

Kordia, S. (2018). ELF-aware teaching in practice: A teacher's perspective. In N.C. Sifakis \& N. Tsantila (Eds.), English as a lingua franca for EFL contexts (pp. 53 - 71). Bristol: Multilingual Matters.

Llurda, E., Bayyurt, Y., \& Sifakis, N. (2018). Raising teachers' awareness about English and English as a lingua franca. In P. Garrett \& J. Cots (Eds.), The Routledge handbook of language awareness (pp. 155-169). London: Routledge.

Lopriore, L., \& Vettorel, P. (2015). Promoting Awareness of Englishes and ELF in the English Language Classroom. In H. Bowles, \& A. Cogo (Eds.), International perspectives on Teaching English as a lingua franca (pp. 13-34). Basingstoke: Palgrave Macmillan.

Mortensen, J. (2013). Notes on English used as a lingua franca as an object of study. Journal of English as a Lingua Franca, 2(1), 25-46.

Pulcini, V. (2014). A new phase for English teacher education in Italy: Testing and training for Tirocinio Formativo Attivo (TFA). Rivista di Lingue, Letterature e Culture Moderne, 1(1), 95-106.

Seidlhofer, B. (1999). Double Standards: Teacher Education in the Expanding Circle. World Englishes, 18(2), 233-245.

Seidlhofer, B. (2004). Research perspectives on teaching English as a lingua franca. Annual Review of Applied Linguistics, 24, 209-239.

Seidlhofer, B. (2009). Common ground and different realities: world Englishes and English as a lingua franca. World Englishes, 28: 236-245. 
Seidlhofer, B. (2011). Understanding English as Lingua Franca. Oxford: Oxford University Press.

Sifakis, N. C. (2007). The education of teachers of English as a lingua franca: A transformative perspective. International Journal of Applied Linguistics, 17 (3), 355-375.

Sifakis, N. C. (2009). Challenges in teaching ELF in the periphery: The Greek context. ELT Journal, 63 (3), 230-237.

Sifakis, N. C. (2014). ELF awareness as an opportunity for change: A transformative perspective for ESOL teacher education. Journal of English as a Lingua Franca, 3(2), 317 335.

Sifakis, N. C. (2019). ELF Awareness in English Language Teaching: Principles and Processes. Applied Linguistics, 40 (2), 288-306, https://doi.org/10.1093/applin/amx034

Sifakis, N. C., \& Bayyurt, Y. (2015). Insights from ELF and WE in teacher training in Greece and Turkey. World Englishes, 34 (3), 471-484.

Sifakis, N., \& Bayyurt, Y. (2018). ELF-aware teaching, learning and teacher development. In J. Jenkins, W. Baker, \& M. Dewey (Eds.), Handbook of English as a Lingua Franca (pp. 456-467). London: Routledge.

Sridhar, K., \& Sridhar, S. (1986). Bridging the paradigm gap: Second language acquisition theory and indigenized varieties of English. World Englishes, 5 (1), 3-14.

Vettorel, P. (2015). World Englishes and English as a Lingua Franca: Implications for teacher education and ELT. Iperstoria, 6, 229-244.

Vettorel, P. (2016). WE-and ELF-informed classroom practices: proposals from a pre-service teacher education programme in Italy. Journal of English as a Lingua Franca, 5(1), 107 133.

Vettorel, P., \& Lopriore, L. (2013). Is there ELF in ELT course-books? Studies in Second Language Learning and Teaching, 3 (4), 483-504.

Widdowson, H. G. (1978). Teaching Language as Communication. Oxford: Oxford University Press.

\section{Copyrights}

Copyright for this article is retained by the author(s), with first publication rights granted to the Journal.

This is an open-access article distributed under the terms and conditions of the Creative Commons Attribution license (CC BY-NC-ND) (http://creativecommons.org/licenses/by-nc-nd/4.0/). 